\title{
Telekardiológia: \\ A telemedicina feladatai és kötelességei
}

\author{
Borbás János dr. ${ }^{1}$ - Forczek Erzsébet dr. ${ }^{2}$ \\ Sepp Róbert dr. ${ }^{1}$ - Bari Ferenc dr. ${ }^{2}$
}

\author{
Szegedi Tudományegyetem, Általános Orvostudományi Kar, \\ ${ }^{1}$ II. Belgyógyászati Klinika és Kardiológiai Központ, ${ }^{2}$ Orvosi Fizikai és Orvosi Informatikai Intézet, Szeged
}

\begin{abstract}
A telemedicina egy fiatal tudomány, amely integrálni hivatott az informatika és telekommunikáció innovációit az orvostudományba. A telemedicina által kínált sikeres lehetőségeknek nagy biztonságú, költséghatékony folyamatokkal kell biztosítani az egészségügyi ellátás terheinek csökkenését. Célunk volt, hogy bemutassuk a telemedicinás projektek fejlődési fázisait a telekardiológia létező megoldásain keresztül. Nemzetközi publikációk segítségével megvizsgáltuk a vérnyomás-távfelügyelet, elektrokardiográfiás távdiagnosztika, implantálható cardioverter-defibrillátor távgondozása és zseb-ultrahangkészülékek múltbéli és jelenlegi helyzetét. Az újdonságok hatékony bevezetéséhez a) számos nemzetközileg elfogadott, magabiztosan reprodukálható „jó gyakorlatra” van szükség annak érdekében, hogy b) a nemzetközi orvostársaságok ajánlásai megszülethessenek, c) garantálni kell továbbá a költséghatékony alkalmazást, a jól megtervezett fenntarthatóságot, d) a személyes adatok biztonságát, illetve e) elengedhetetlen a szakemberek, betegek képzésének fejlesztése. A munkánk során tárgyalt sztenderdeket javasoljuk a telemedicinás folyamatok fejlesztői számára, hogy a klinikai gyakorlatba eredményesebben tudjanak belépni új termékeikkel. Biztató, hogy a telekardiológia jelenlegi szereplői között találunk a fenti kritériumoknak részben vagy teljesen megfelelőket is. A további fejlődés hozzájárulhat az egészségügy anyagi fenntarthatóságához és az emberierőforrás-korlátok leküzdéséhez.
\end{abstract}

Orv Hetil. 2017; 158(44): 1741-1746.

Kulcsszavak: telemedicina, kardiológia, okostelefon, mobiltelefon-alkalmazás

\section{Telecardiology: Tasks and duties of telemedicine}

Telemedicine is a young science that integrates innovations of information-technology and telecommunications into medical science. A successful telemedicine procedure should guarantee reduced workload of the healthcare system with well secured and cost-effective processes. Our goal was to collect the development phases of telemedicine projects through existing telecardiology solutions. Subsequent to reviewing international publications we analyzed the past and present situation of blood pressure monitoring, remote diagnostics of electrocardiography, implantable cardioverter defibrillator monitoring and pocket ultrasound devices. In case of new solutions (a) several internationally accepted, confidently reproducible "good practices" are needed for creating (b) guidelines and recommendations of international medical associations. They have to ensure (c) cost-effective work, with well-designed sustainability and $(\mathrm{d})$ patient confidentiality. Improving (e) education for professionals and patients is essential. We recommend to telemedicine developers to use our standards in order to introduce their products more effectively into clinical practice. It is encouraging that current possibilities of telecardiology partly or fully meet the aforementioned criteria. Further development of the topic can contribute to financial sustainability of our healthcare and might be able to resolve limitations of human resources.

Keywords: telemedicine, cardiology, smart phone, mobile application

Borbás J, Forczek E, Sepp R, Bari F. [Telecardiology: Tasks and duties of telemedicine]. Orv Hetil. 2017; 158(44): 1741-1746.

(Beérkezett: 2017. augusztus 11.; elfogadva: 2017. szeptember 2.) 


\section{Rövidítések}

AHA = (American Heart Association $)$ Amerikai Szív Társaság; $\mathrm{ECOST}=($ Effectiveness and Cost Of ICD follow-up Schedule with Telecardiology) Telekardiológia módszerével történó ICD-gondozás hatás- és költségvetési tanulmánya; EFFECT study $=($ Enhanced Feedback for Effective Cardiac Treatment $)$ Továbbfejlesztett visszajelzés a hatásos kardiológiai kezelésről; $\mathrm{EKG}=$ elektrokardiogram; ESC $=($ European Society of Cardiology) Európai Kardiológiai Társaság; ESH = (European Society of Hypertension) Európai Hypertonia Társaság; ICD = implantálható cardioverter-defibrillátor; $\mathrm{RR}=$ vérnyomás; $\mathrm{UH}=$ ultrahang; USD = (United States dollar $)$ amerikai dollár

A cardiovascularis betegségek gyógyításában nélkülözhetetlen a keringési rendszer strukturális és funkcionális monitorozása, legyen szó a European Society of Hypertension (ESH), a European Society of Cardiology (ESC) vagy az American Heart Association (AHA), American Stroke Association klinikai ajánlásairól. Az ajánlásoknak megfelelően a klinikai döntéshozatalban kiemelkedő szerepet kap a most már „klasszikussá” vált bioparaméterek (vérnyomás, pulzus stb.) monitorozása. A minél szélesebb körú monitorozást a telemedicina eszközeivel is támogathatjuk. Ennek kardiológiai vonatkozású példáit munkánk során részletesebben is tárgyaljuk. Nyilvánvaló elvárás, hogy minden egyes, orvosi gyakorlatba épített új telemedicinás eszközzel és alkalmazással egyre könnyebb és pontosabb legyen a betegek követése, monitorozása és oktatása. Ebbő́l következik tehát, hogy egy jó megoldás könnyebben elérhetôvé teszi a primer és szekunder prevenciót és a terápia-rehabilitáció kapcsán segít a compliance fenntartásában.

A telemedicina hivatott integrálni az informatika és telekommunikáció innovációit az orvostudományba. Fejlódésének és alkalmazásának lényege, hogy a szakorvos szemléletének és tudásának egy része elérhetővé váljon a háziorvosi rendelőben, a mentőautóban és a beteg otthonában is, valós időben történő kommunikációval vagy elcsúsztatva.

Az eddigi eredmények azt mutatják, hogy a telemedicinában nagy orvosszakmai, gazdasági és egészségélmény-fejlődési potenciál van jelen. Bevezetése azonban körültekintő vizsgálatokat igényel, akár a prevenció egyes ágait, akár a diagnosztizálás, gyógyítás és rehabilitáció folyamatát tekintjük [1].

Jelenleg az eszközgyártók kínálatában kevés a jó minôségű, validált hardver vagy az orvosilag megfelelő hardverhez kapcsolódó hatékony szoftver. A hatékonynak tünő komplett megoldásokat (szolgáltatások) pedig csak kevés alkalommal vizsgálják tudományos igénnyel. Ennek oka lehet: a) az eszközök és alkalmazások gyors változása, b) a változó gyógyítási körülmények, c) a szereplők bizonyos kompetenciájának új szinten történő megjelenése, valamint d) tudományos, orvosszakmai, gazdasági, jogi, adatvédelmi, felelősségi kérdések is.

Örvendetes azonban, hogy egy napjainkban megjelent tanulmányban [2] leírtak szerint már elkezdődött a fenti kérdések vizsgálata a nagy nemzetközi kardiológustársaságoknál is. Intézetünk korábbi publikációja a teledermatológia témakörében felhívja a figyelmet, hogy szükség van magyar nyelvú, orvosidiszciplína-specifikus publikációkra is [3].

\section{Háttér - a telemegoldások fejlődésének logikai lépcsője}

A telemedicinás megoldások sikeréhez feltétlenül szükség van a jó gyakorlatok összegyújitésére. A jó gyakorlatok (good practice) ez esetben olyan telemedicinás projekteket írnak le, amelyek tudományosan is igazolt eredményeket mutatnak fel a betegek egészségének vagy az egészségügy fenntarthatóságának érdekében. A jó gyakorlatok legfontosabb tulajdonsága, hogy ezen eredmények reprodukálhatóak, és a validálást követően akár modellként is szolgálhatnak nagy populációt érintő folyamatokhoz.

Nyilvánvaló, hogy kellő számú jó gyakorlat nélkül nem születhetnek nagy nemzetközi szervezetek által támogatott ajánlások. Az ajánlások nyitják meg a lehetőséget az egységes, nagy populáción történő vizsgálatokra, gazdasági, biztonságtechnikai értékelésre és jogi szabályozásra. Az is nyilvánvaló, hogy a telemedicina esetében különös jelentőségû a képzés, mivel a beteg és hozzátartozója, az egészségügyi dolgozó és a szakorvos megosztott felelősséggel, együttesen vesznek részt a döntésekben. A nemzetközi ajánlások és hatástanulmányok egymásra épülése hozzásegít, hogy a képző centrumok megfelelő szintű oktatást biztosíthassanak, vagyis optimalizált ismeretanyagot és gyakorlatorientált tudást adhassanak át a jelenlegi és a következő generációknak.

A távfelügyeleti rendszerek ajánlásainak mielőbbi megjelenése azért is lenne fontos, hogy orvosilag ellenőrzött, az orvosi irányelveket szigorúan figyelembe vevő egyedi szempontrendszerek terjedjenek el, vagyis az egyedi fejlesztések egységes irányba mozduljanak el. Az ajánlások hiánya miatt már ma is hatalmas különbségek vannak a telemedicinás rendszerek között, ahogy ezt Yanicelli és mtsai bemutatták [4] a szívelégtelenség monitorozása kapcsán.

A fentieket alátámasztja, hogy a becslések szerint jelenleg már több mint 250000 olyan egészségügyi megoldás létezik, amely okostelefonra épül. 2013-ban az üzleti bevétel a telemedicina piacán 2,4 milliárd USD volt. 2016-ra ez az árbevétel elérhette a 12,5 milliárd USD-t. 2020-ra akár 40 milliárdos piacról beszélhetünk. Fenyegető a veszély azonban, hogy tudományos munkacsoportok és szakmai közösségek összefogása és ajánlásai nélkül a telemedicina piaca önállóan nem fogja elérni a várva várt kritikus pontot, amikor a mennyiségi kínálat hirtelen átlendül minőségibe, ezáltal elérve az előzőleg érintett egészségügyi célokat. Hasonló következtetésre jutott egy norvég kutatócsoport is, akik szintén paradigmaváltást várnak a telemedicinás kutatások területén [5]. 


\section{Célkitüzés}

Jelen összefoglalás célja a telemedicinás eszközökkel szembeni elvárások és kihívások bemutatása a kardiológia nemzetközi irodalmában megjelent fontos írásokon keresztül. Szeretnénk továbbá összegyüjteni a telemedicinás megoldások fejlesztési fázisait, hogy a kutatók/fejlesztők eredményesen tudjanak belépni új termékeikkel a klinikai gyakorlatba. A jelenleg létező összes, kardiológiát érintő telemedicinás fejlesztés bemutatása meghaladná munkánk terjedelmét. Így közleményünkben nincs lehetőségünk írni például az ígéretesnek tünő rehabilitációs megoldásokról [6] vagy a szúréseket támogató online tesztekról.

\section{Alapellátás - vérnyomás-távfelügyelet}

\section{Evidenciák és jó gyakorlatok gyüjtése}

Számos távfelügyeleti rendszer van forgalomban, amelyek képesek a laikusok által mért vérnyomás-paraméterek online továbbítására. Az eredményeket legtöbb esetben felhőalapú tárhelyen rögzítik, így ezek könnyen hozzáférhetőek a beteg, illetve az egészségügyi szakszemélyzet számára.

Ez esetben a vérnyomás mérését a beteg végzi. A továbbított mérési eredmények felügyeletét és értékelését a szakorvos iránymutatásai mellett a körzeti nővér, ápoló, gyógyszerész vagy háziorvos végezheti, azonnali visszacsatolási lehetőséggel. Elterjedése esetén, egy jól múködő alapellátás keretein belül, jelentős terhet vehetnénk le a szakellátásról.

A vérnyomásmérő telemedicinás monitorozására két nagy, áttekintő jellegű tanulmány is született, amelyek a jó gyakorlatok gyűjtését tűzték ki célul.

2013-ban Zullig és mtsai hét tanulmány áttekintésével próbáltak képet alkotni az otthoni vérnyomásmérés távfelügyeletének gyakorlatáról [7]. Összesen közel 2000 ember 6-24 hónapig tartó utánkövetése történt, ahol a hagyományos eljárásokhoz képest trendszerü, alkalmanként szignifikáns vérnyomáscsökkenést értek el a vizsgált betegeknél. Ugyancsak pozitív volt annak a 31 tanulmányból álló, 11000 beteggel kapcsolatos összegzésnek az eredménye, amelyet 2014-ben Darshi Sivakumaran és mtsai jelentettek meg [8].

Bár a végeredményeket tekintve a vizsgált gyakorlatok az elvárt eredménnyel zárultak, mindkét összefoglaló tanulmány szerzője felhívta a figyelmet arra, hogy a kutatások tervezése és kivitelezése nem volt egységes. Változó időtartamú, különböző telemedicinás módszerű és eltérő egészségügyi ellátási szinten történő vérnyomás-monitorozást nehéz volt precízen összehasonlítani.

Levonható a következtetés, hogy a vérnyomás távfelügyelete kapcsán több hangsúlyt kellene fektetni az általános elvek tisztázására, a hosszú távú eredmények átgondolására, a jó gyakorlatok keresésére az alapellátás különböző szintjein belül, valamint a leghatékonyabb távfelügyelet elérésére. További tanulmányokra volna szükség, amelyek alapvető célja nem az egyes üzleti modellek alátámasztása, hanem tudományos bizonyítékok szolgáltatása, figyelembe véve a már meglévő nem telemedicinás ajánlásokat is. Remek példa erre az új metodikákat vizsgáló telemedicinás vérnyomásmérő eljárás [9].

\section{Sürgősségi ellátás - EKG-távdiagnosztika}

\section{Nemzetközi ajánlások születése}

Telemedicinás EKG-távfelügyeleti rendszerek a speciális szaktudású egészségügyi ellátóhelyektől távol is képesek EKG készítésére, akár laikus által kivitelezve azt. A rendszer az elkészült felvételeket képes eljuttatni a diagnózis felállítását végző központba, ahol a diagnózis felállítója térben és akár időben is távol van a betegtől.

Nemzetközi [10] és hazai viszonylatban is létezik jó gyakorlat eredményességéról szóló publikáció [11] a témában. A telemedicina ígéretes módszernek látszik akár aritmia, akár szívizominfarktus távdiagnosztikájában. Ezért a jó gyakorlatok összegyüjtésére is voltak már törekvések [12, 13].

A nemzetközi kardiológustársaságoknál azonban se konzol-, se okostelefon-alapú ajánlást nem találtunk az EKG-távdiagnosztikára vonatkozóan. Találtunk két nemzeti szintüt [14-16], amelyek szociológiai és infrastrukturális különbségek miatt szélesebb körű felhasználásra csak korlátozottan alkalmasak. A brazil leírás szerint a szívizominfarktus kimutatása céljából készült EKG általában automatikusan vagy alapellátásban dolgozó szakember segítségével történt, míg a felvétel értékelését minden esetben szakorvos végezte. Az ajánlás szerint a klinikai döntéshozatalba bevonták az alapellátót és a szakorvost egyaránt, ezáltal a felelősség is megoszlott. Létezik egy nemzetközi információtechnológiai útmutató a biztonságos mobiltelefonos EKG-regisztrálásra, ami része lehetne egy egészségügyi ajánlásnak [17].

Egy 2016-ban született, EKG-val kapcsolatos tanulmány szerint a telemedicinás eljárásokat külön nem részletező ajánlások ugyan mûködnek telemedicinás eszközökkel [18], de a szerzők felhívják a figyelmet (annak ellenére is, hogy a projektek sikeresek voltak), hogy szükség volna több egységesített, átfogó képet alkotó, a sürgôsségi ellátást segítő nemzetközi telemedicinás ajánlásra. A nagyobb méretû hatástanulmányok elkészítéséhez szükség volna, az ajánlásokon túl, további jó gyakorlatok felkutatására és részterületek ajánlásainak elkészítésére is.

\section{Járóbeteg-szakellátás - ICD távgondozása}

\section{Fenntarthatóság és biztonság - hatástanulmányok}

A szívmegállással fenyegetett betegek implantálható cardioverter-defibrillátor (implantable cardioverter defibrillator - ICD) beültetésével élhetnek tovább, amelynek 
során a készülék állandó jelleggel regisztrálja a beteg szívmúködése kapcsán keletkező elektromos jeleket és aritmia esetén sokkolja a szívet. A keletkező regisztrátumot bizonyos ICD-készülékek képesek eljuttatni a szakorvoshoz, így lehetôség nyílik a beteg gondozására (gyógyszerek átgondolására, eszköz beállítására) a specializált centrumoktól távol is.

Az ICD-k felhasználása jól mutatja, hogy egy telemedicinás eljárás javíthatja a járóbeteg-ellátást a távszupervízió során. A kommunikációs eszközökön keresztül bevonható távoli szakember is, és a távmanipuláció révén a specialista távolról elvégezheti az interakciót igénylő módosítást.

Már 2011-ben megjelent egy konszenzusos ajánlás a beültethető eszközök szakorvos által történő távfelügyeletéról [19]. Az ICD-vel történő távmonitorozás gyors fejlődéséhez az is hozzájárulhatott, hogy magának az ICD múködésének esetleges hibáját már távmonitorozták korábban is [20].

Az ajánlás mentén kialakult jó gyakorlatokat [21-26] 2015-ben gyưjtötték össze Giuseppe Boriani és mtsai, amelynek kapcsán nemzetközi ajánlások születtek [27, 28]. Eközben jelent meg az egyik legnagyobb hatástanulmány, az EFFECT study, amely közel ezer beteget követett legalább 12 hónapig. Az eredmények bizonyították, hogy a távfelügyeleti eljárás csökkenti a halálozást és a felesleges hospitalizációt is [29].

A guideline és hatástanulmány megszületése után felmerült az igény a rendszeres, rutinszerű használat bevezetésére, de ehhez szükség volt megfelelő költséghatékonysági és fenntarthatósági vizsgálatokra. 2015-re született meg az ECOST tanulmány, amely 433 francia beteget vizsgált az ICD-beültetés utáni két évben. A betegek felének utánkövetése a telemonitorozás módszerével történt. Franciaországi egészségbiztosítási rendszer alapján a telemonitorozás trendszerúen olcsóbbnak bizonyult a kórházi költségekben, és szignifikánsan olcsóbbnak bizonyult az eszköz kezelése a nem direkt kórházi költségek tekintetében [30]. Giuseppe Boriani felhívta továbbá a figyelmet, hogy a 15 európai ország egészségbiztosításának különbségei nagy problémát jelenthetnek a jövőben, ha rutinszerü bevezetésre kerülne sor Európában.

\section{Sürgősségi/kardiológiai osztályos szakellátás - A zseb-ultrahangkészülékek alkalmazása}

\section{Szakemberek képzése}

A hordozható ultrahangkészülékek olyan orvosi képalkotó eszközök, amelyek diagnosztikai célúak, de kisebbek és könnyebben hordozhatók konzol stílusú társaiknál, legtöbb esetben akár kézben is hordozhatók, ezért szakorvosi háttérrel távdiagnosztikai célokra szintén alkalmazhatóak. Az eszköz segítségével történő klinikai döntéshozatal jelenleg szakorvosi vizsgához kötött, a döntési folyamat támogatása további szakorvosok bevonásával történhet.

Napjainkban a legtöbb hordozható ultrahangkészülék az okostelefonokhoz csatlakoztatható szenzorként is múködik, így az elkészült képeket és lemért paramétereket továbbíthatják a döntéshozó centrumba.

Európában 2011 óta nemzetközi ajánlás szabályozza a felhasználásukat [31], amely a következő nyolc pontot foglalja magába:

1. Fizikális vizsgálat kiegészítése az intenzív osztályokon és coronariaőrzőkben.

2. Veszélyes környezetben gyors bevezető szűrővizsgálat.

3. Részleges kardiológiai tanácsadás kórházon belül és kívül.

4. Mentőben első észleléses kardiológiai értékelés.

5. Szűrőprogramhoz iskolákban, gyárakban, közösségi szolgálatokban.

6. Hallgatók képzése.

7. Oktatási segédeszköz.

8. Tüdőfolyadék-mennyiség mérése.

A fenti tevékenységre alkalmas eszközök használata lehetővé teszi a gyorsabb és egyértelmúbb klinikai diagnózis megalkotását. Csökkenti az egészségügyi kiadásokat, csökkenti a várólistát a drágább vizsgálatokra.

Költséghatékonyságuk mértékét és a diagnosztikában betöltött szerepüket azonban a klinikai felhasználás minősége szabja meg, amely szükségszerüen múlik a megfelelő képzésen, a felhasználók oktatásán.

A nemzetközi ajánlások és tanulmányok pozitívan nyilatkoznak azokról az esetekről, amikor a zseb-ultrahangkészülékeket echokardiográfiában jártas szakemberek alkalmazzák. Ugyancsak pozitív a megítélése a krónikus betegségek utánkövetésében [32], kardiológiai osztályos felhasználásban [33] és a sürgősségi alkalmazásban „fókuszált echokardiográfiás” vizsgálatoknál [34, 35]. A fentieket támasztják alá Mariana Mirabel és mtsai, akik közel két tucat tanulmány eredményeit összesítették. A képzett vizsgálók jó képet vázoltak az eszköz képességeiról és használhatóságáról [36] (1. táblázat).

A zseb-ultrahangkészülékekre nagy igény mutatkozik, és sokan elvárják, hogy ne csak a kardiológiában, hanem az általános orvoslásban, aneszteziológiában, sürgősségi ellátásban, belgyógyászatban is használatosak legyenek. Ezen igények kielégítésére belgyógyászrezidensek számára indított speciális képzésen $[37,38] 12$ hónapig havi 45 perces előadáson vettek részt a rezidensek, alkalmanként 30 perc gyakorlati idővel. A képzés használhatóságának igazolására az előadásokat követően fókuszált echokardiográfiás vizsgálatot végeztettek 21 résztvevővel. 107 kritikus állapotú betegnél sikerült jó eredménynyel megállapítaniuk az életet veszélyeztető tüdőödéma bizonyos jeleit. A vizsgálatokon készült képeket minden esetben ultrahangkép-értelmezésben jártas szakemberrel kontrolláltatták [39]. 
Zseb-ultrahangkészülék összehasonlítása konzol típusú készülékekkel

\begin{tabular}{ll}
\hline Paraméter & Pontosság \\
\hline Bal kamra mérete & Jó \\
Bal kamrai szisztolés funkció & Jó \\
Regionális falmozgászavar & Jó \\
UH tüdő „comet” & Jó \\
Pleuralis folyadék & Jó \\
Inferior vena cava & Változó \\
Bal pitvar mérete & Elfogadható \\
Pericardialis folyadék & Kiváló \\
Aortabillentyú-betegség jelenléte/súlyossága & Elfogadható \\
Mitralisbillentyü-betegség jelenléte/súlyossága & Elfogadható \\
Hasi aortaaneurysma & Jó \\
Jobb kamra & Változó \\
\hline
\end{tabular}

Táblázat magyarázó szövege:

Változó: Tanulmányonként változó a szenzitivitás/specificitás.

Kiváló: Szenzitivitás $\geq 90 \%$ és a specificitás $\geq 95 \%$, akár nem szakorvosok bevonásával is.

Jó: Szenzitivitás $>90 \%$ és specificitás $>90 \%$, echokardiográfiában jártas szakorvos által kivitelezve.

Elfogadható: Szenzitivitás $\approx 80 \%$, specificitás $\approx 80 \%$.

Forrás: Mirabel M, et al., 2015 [36].

A képzésben részt vevő és vizsgálatokat végző szakemberek egybehangzó véleménye szerint kifejezetten hasznos lenne megfelelő minőségü, standardizált oktatási kritériumokat és új oktatási programokat felépíteni az ultrahang használatához. Csak a megfelelő oktatás képes garantálni az egyes megoldások hatékonyságát, biztonságát, fenntarthatóságát.

\section{Következtetés}

A mára már jól múködő egészségügyi tevékenységeket a nagyobb hatásfok és alacsonyabb költségek érdekében telemedicinás megoldásokkal lenne célszerü támogatni. Ennek köszönhetően az alacsonyabb szintű ellátóhelyek szakmai kompetenciája emelhető lenne a távolból adott konzíliumok segítségével, továbbá jelentős előny lenne a betegek sürgősségi ellátóhelyekre történő szállításának racionalizálása.

A munkánk során tárgyalt legfontosabb lépések teljesülése esetén a telemedicinás eljárások magabiztosan garantálnák a nagyobb biztonságú és költséghatékonyabb folyamatokat, a szakorvosi és klinikai terhelés csökkentését.

A bemutatott sikertörténeteket és megtorpanásokat összefoglalva az alábbi lépésekre feltétlenül szükség lenne minden telemedicinás fejlesztés során:

- Megfelelő jó gyakorlatok folyamatos gyüjtésére, jól strukturált, könnyen kereshető adatbázisok létrehozására, adatbiztonsági protokollok kidolgozására, ko- moly szakmai kontroll alatt történő nemzetközi ajánlások szerkesztésére és hatástanulmányok készítésére.

- A létrejött ajánlások alapján a megfelelő financiális háttér kialakítására és a fenntarthatóság megszervezésére.

- Az egészségügy kritériumainak megfelelő, validált eszközök és alkalmazások fejlesztésére és a mindennapi betegellátási gyakorlatba történő integrálására.

- A telemedicinában jártas, a betegellátásban dolgozó orvosok, az egészségügyi szakszemélyzet és az érintett laikus lakosság képzésére.

Szerencsére a telekardiológia jelenlegi eszközei közül találunk a fenti kritériumoknak részben vagy egészben megfelelőt is.

Azonban további hazai tapasztalatokra, szabályozásokra és bővítésekre lenne szükség az alap-, a sürgősségi és szakellátás területén, hogy kialakuljon az anyagi fenntarthatóság és az emberi erőforrások korlátai leküzdhetők legyenek.

Anyagi támogatás: A közlemény megírása anyagi támogatásban nem részesült.

Szerzői munkamegosztás: A szerzők közösen írták a kéziratot. A cikk végleges változatát valamennyi szerző elolvasta és jóváhagyta.

Érdekeltségek: A szerzőknek nincsenek érdekeltségeik.

\section{Köszönetnyilvánítás}

Köszönettel tartozunk Dr. Nyolczas Noémi tanárnőnek, Dr. Fidrich Mártának és Dr. Gyimóthy Tibor professzor úrnak, amiért munkájukkal támogatják a telemedicina és telekardiológia hazai fejlődését.

\section{Irodalom}

[1] Heinzelmann PJ, Lugn NE, Kvedar JC. Telemedicine in the future. J Telemed Telecare 2005; 11: 384-390.

[2] Schwamm LH, Chumbler N, Brown E, et al. Recommendations for the implementation of telehealth in cardiovascular and stroke care: A Policy Statement From the American Heart Association. Circulation 2017; 135: e24-e44.

[3] Danis J, Forczek E, Bari F. Telemedicine in dermatological practice: teledermatology. [A telemedicina alkalmazása a bőrgyógyászatban: a teledermatológia.] Orv Hetil. 2016; 157: 363-369. [Hungarian]

[4] Yanicelli LM, Parodi NF, Goy CB, et al. Heart failure management: comparative study of telemonitoring systems and the medical consensuses. In: Braidot A, Hadad A. (eds.) VI Latin American Congress on Biomedical Engineering CLAIB 2014, Paraná, Argentina 29, 30 \& 31 October 2014. IFMBE Proceedings 49. Springer International Publishing, Switzerland, 2015; pp. 821824.

[5] Clemensen J, Rothmann MJ, Smith AC, et al. Participatory design methods in telemedicine research. J Telemed Telecare 2016 Dec 27. doi: 10.1177/ 1357633X16686747 [Epub ahead of print]

[6] Tomcsányi J, Bezzeg P. Home ECG monitoring of high-risk post-myocardial infarction patients. [Otthoni EKG-monitorozás magas rizikójú posztinfarktusos betegeken.] Orv Hetil. 2009; 150: 985-988. [Hungarian] 
[7] Zullig LL, Melnyk SD, Goldstein K, et al. The role of home blood pressure telemonitoring in managing hypertensive populations. Curr Hypertens Rep. 2013; 15: 346-355.

[8] Sivakumaran D, Earle KA. Telemonitoring: use in the management of hypertension. Vasc Health Risk Manag. 2014; 10: 217 224.

[9] Verberk WJ, Omboni S, Kollias A, et al. Screening for atrial fibrillation with automated blood pressure measurement: Research evidence and practice recommendations. Int J Cardiol. 2016; 203: 465-473.

[10] Nguyen HH, Van Hare GF, Rudokas M, et al. SPEAR Trial: Smartphone Pediatric ElectrocARdiogram Trial. PLoS One 2015; 10: e0136256.

[11] Papai G, Racz I, Czuriga D, et al. Transtelephonic electrocardiography in the management of patients with acute coronary syndrome. J Electrocardiol. 2014; 47: 294-299.

[12] De Waure C, Cadeddu C, Gualano MR, et al. Telemedicine for the reduction of myocardial infarction mortality: a systematic review and a meta-analysis of published studies. Telemed J E Health 2012; 18: 323-328.

[13] Al-Zaiti SS, Shusterman V, Carey MG. Novel technical solutions for wireless ECG transmission \& analysis in the age of the internet cloud. J Electrocardiol. 2013; 46: 540-545.

[14] Oliveira MT Jr, Paula LJ, Marcolino MS, et al. Executive summary - guideline on telecardiology in the care of patients with acute coronary syndrome and other cardiac diseases. Arq Bras Cardiol. 2015; 105: 105-111.

[15] Caldarola P, Gulizia MM, Gabrielli D, et al. ANMCO/SIT Consensus document: telemedicine for cardiovascular emergency networks. Eur Heart J Suppl. 2017; 19(Suppl D): D229-D243.

[16] Caldarola P, Gulizia MM, Gabrielli D, et al. ANMCO/SIT Consensus document: Telemedicine and the emergency/urgency care network. G Ital Cardiol. (Rome) 2016; 17: 508-528.

[17] Cinaglia P, Tradigo G, Guzzi PH, et al. Design and implementation of a telecardiology system for mobile devices. Interdiscip Sci. 2015; 7: 266-274.

[18] Brokmann JC, Conrad C, Rossaint R, et al. Treatment of acute coronary syndrome by telemedically supported paramedics compared with physician-based treatment: a prospective, interventional, multicenter trial. J Med Internet Res. 2016; 18: e314.

[19] Dubner S, Auricchio A, Steinberg JS, et al. ISHNE/EHRA expert consensus on remote monitoring of cardiovascular implantable electronic devices (CIEDs). Europace 2012; 14: 278-293.

[20] Hauck M, Bauer A, Voss F, et al. "Home monitoring" for early detection of implantable cardioverter-defibrillator failure: a single-center prospective observational study. Clin Res Cardiol. 2009; 98: 19-24.

[21] Varma N, Ricci RP. Telemedicine and cardiac implants: what is the benefit? Eur Heart J. 2013; 34: 1885-1895.

[22] Landolina M, Perego GB, Lunati M, et al. Remote monitoring reduces healthcare use and improves quality of care in heart failure patients with implantable defibrillators: the evolution of management strategies of heart failure patients with implantable defibrillators (EVOLVO) study. Circulation 2012; 125: 29852992.

[23] Boriani G, Da Costa A, Ricci RP, et al. The MOnitoring Resynchronization dEvices and CARdiac patiEnts (MORE-CARE) randomized controlled trial: phase 1 results on dynamics of early intervention with remote monitoring. J Med Internet Res. 2013; 15: el67.

[24] Burri H. Remote follow-up and continuous remote monitoring, distinguished. Europace 2013; 15(Suppl 1): il4-il6.

[25] Hindricks G, Elsner C, Piorkowski C, et al. Quarterly vs. yearly clinical follow-up of remotely monitored recipients of prophylactic implantable cardioverter-defibrillators: results of the REFORM trial. Eur Heart J. 2014; 35: 98-105.

[26] Heidbuchel H, Hindricks G, Broadhurst P, et al. EuroEco (European Health Economic Trial on Home Monitoring in ICD Patients): a provider perspective in five European countries on costs and net financial impact of follow-up with or without remote monitoring. Eur Heart J. 2015; 36: 158-169.

[27] Boriani G. Remote monitoring of cardiac implantable electrical devices in Europe: quo vadis? Europace 2015; 17: 674-676.

[28] Boriani G, Nesti M, Ziacchi M, et al. Cardiac resynchronization therapy: an overview on guidelines. Card Electrophysiol Clin. 2015; 7: 673-693.

[29] De Simone A, Leoni L, Luzi M, et al. Remote monitoring improves outcome after ICD implantation: the clinical efficacy in the management of heart failure (EFFECT) study. Europace 2015; 17: 1267-1275.

[30] Guédon-Moreau L, Lacroix D, Sadoul N, et al. Costs of remote monitoring vs. ambulatory follow-ups of implanted cardioverter defibrillators in the randomized ECOST study. Europace 2014; 16: 1181-1188.

[31] Sicari R, Galderisi M, Voigt JU, et al. The use of pocket-size imaging devices: a position statement of the European Association of Echocardiography. Eur J Echocardiogr. 2011; 12: 85-87.

[32] Gustafsson M, Alehagen U, Johansson P. Imaging congestion with a pocket ultrasound device: prognostic implications in patients with chronic heart failure. J Card Fail. 2015; 21: 548-554.

[33] Khan HA, Wineinger NE, Uddin PQ, et al. Can hospital rounds with pocket ultrasound by cardiologists reduce standard echocardiography? Am J Med. 2014; 127: 669.el-e7.

[34] De Backer D, Fagnoul D. Pocket ultrasound devices for focused echocardiography. Crit Care 2012; 16: 134.

[35] Biais M, Carrié C, Delaunay F, et al. Evaluation of a new pocket echoscopic device for focused cardiac ultrasonography in an emergency setting. Crit Care 2012; 16: R82.

[36] Mirabel M, Celermajer D, Beraud AS, et al. Pocket-sized focused cardiac ultrasound: strengths and limitations. Arch Cardiovasc Dis. 2015 ; 108: 197-205.

[37] Kimura BJ, Gilcrease GW 3rd, Showalter BK, et al. Diagnostic performance of a pocket-sized ultrasound device for quick-look cardiac imaging. Am J Emerg Med. 2012; 30: 32-36.

[38] Vignon P, Mücke F, Bellec F, et al. Basic critical care echocardiography: validation of a curriculum dedicated to noncardiologist residents. Crit Care Med. 2011; 39: 636-642.

[39] Mai TV, Ahn DT, Phillips CT, et al. Feasibility of remote realtime guidance of a cardiac examination performed by novices using a pocket-sized ultrasound device. Emerg Med Int. 2013; 2013: 627230

(Borbás János dr., Szeged, Semmelweis u. 8., 6725 e-mail: borbas.janos@med.u-szeged.hu) 